\title{
Assessment of the adaptive potential and ecological plasticity of a new variety of spring barley Fermerskiy for Northwest Russia
}

\author{
Tatiana Radyukevich ${ }^{1}$, Lyudmila Kartasheva ${ }^{1}$ and Dmitry Danilov ${ }^{1,2^{*}}$ \\ ${ }^{1}$ Russian Potato Research Center, Leningrad Scientific Research Institute of Agriculture BELOGORKA, 1, Institutskaya Street, \\ Belogorka, Leningrad Region 188338, Russia \\ ${ }^{2}$ Saint-Petersburg State Forest Technical University named after SM Kirov, 5, Institutsky Lane, Saint-Petersburg 194021, Russia
}

\begin{abstract}
In Northwest Russia, creation and introduction of new varieties of cereals characterized by early maturity, high adaptive potential and ecological plasticity is one of the most important tasks. A new generation of barley varieties is needed that combines high yields with early maturity, high feed qualities of grain, and resistance to lodging and grain shedding. We carried out field and laboratory studies of a new variety of spring barley Fermerskiy in an experimental field of the Leningrad Research Institute of Agriculture "Belogorka". In 2021, Fermersky was transferred for state variety testing. The variety is midseason and the growing season is 72-87 days. Over three years of competitive variety testing (2018-2020), the yield increase was $1.25 \mathrm{t} / \mathrm{ha}$ relative to the Suzdalets standard ( $3.12 \mathrm{t} / \mathrm{ha})$. The highest yield of $5.27 \mathrm{t} / \mathrm{ha}$ was obtained in 2019, under conditions of low moisture supply. The average index of ecological plasticity (Jsp) was 1.48 ( $\min 1.11, \max 1.94)$. The adaptive potential (ds/dk) was 7.91 ( $\min 6.92$, max 9.08), The Fermerskiy variety consistently formed a high yield and was characterized by ecological plasticity, early maturity, and resistance to diseases and lodging.
\end{abstract}

\section{Introduction}

Barley is a genus of the family Gramineae; it is one of the most ancient grain crops cultivated by man and one of the most ancient cultivated plant. In the Middle East, wheat and barley were domesticated by 10,000 years ago [1-6]. Wild barley (Hordeum vulgare) grows over a vast area, from Crete and North Africa in the west to the Tibetan mountains in the east. Globally, barley occupies over 90 million hectares. In terms of the area harvested and gross grain harvest, it is in fourth place after wheat, rice and maize, and in terms of yield, in third place, being second only to maize and rice [6-11].

Barley is a fast and early ripening crop, and one of the most adapted to growing in a wide variety of climatic conditions, from subarctic to subtropical [12-16]. Barley is widespread in various climatic zones (except for equatorial), up to 70 degree North. In the mountains it rises above all other crops. For winter varieties, the main risk factors are extremely low winter temperatures and overheating during grain ripening. Temperate zone is the most suitable one for cultivation of barley. Barley adapts to different soils and, in comparison with wheat, is more resistant to drought and less demanding in terms of soil fertility [17].

Barley grain is widely used for technical and feed purposes, and as food, including in the brewing industry and in the production of pearl barley and barley porridge [18-21]. The grain of barley contains: 7-15\% of proteins, $65 \%$ of carbohydrates, $2 \%$ of fat, $5.0-5.5 \%$ of fibre, and $2.5-2.8 \%$ of ash. Barley protein contains all essential amino acids, including particularly deficient and the most valuable ones: lysine and tryptophan. Barley grain is widely used as a concentrated feed for livestock; $1 \mathrm{~kg}$ contains 1.27 feed units and $100 \mathrm{~g}$ of digestible protein. The high content of hordein in barley grain helps suppress the development of gram-positive bacteria, which has a beneficial effect for animal health. Barley straw is superior in nutritional value to rye and wheat; when steamed, it is well eaten by animals. Barley is one of the most valuable concentrated animal feeds, as it contains complete protein, and is rich in starch. In Russia, up to $70 \%$ of barley is used as fodder [21, 22].

Traditionally, spring malting barley was grown in areas with moderate temperatures and sufficient rainfall (650 mm/year) throughout the growing season [7-10].

Depending on the climate, variety, agricultural technology and other conditions, the yield of barley can vary from 0.8 to 7.5 tons per hectare. In dry climates, higher yields can be achieved with irrigation.

On a commercial scale, barley is used for livestock feed, for the production of malt, an essential ingredient in brewing technology, and as food. For each of these purposes, special varieties have been developed. Barley is mainly used as fodder. Only $13 \%$ of the global volume produced is used for malt production.

Barley is the main grain feed crop. The main producers of barley are the European Union, Russia,

\footnotetext{
Corresponding author: stown200@ mail.ru
} 
Ukraine, Canada, Australia, Turkey and the United States. The European Union produces $42.3 \%$ of the world's barley. The leaders are France and Germany. Despite a decrease in demand for livestock feed, the Russian Federation ranks first in the world in terms of the barley area harvested. In 2015, the main importer of Russia's barley was Saudi Arabia (57.3\% of the total volume). Also, large volumes of Russia's barley are supplied to Iran, Jordan, Kuwait, Libya and Tunisia [611]. Barley production totals 132 million tons per year. Global production of barley doubled between 1961 and 1979, peaking in 1991 at 170 million tonnes. Since then, the production has dropped to 132 million tons (78\% of the maximum) harvested from 48.5 million hectares. The Russian Federation has the largest barley area harvested (16\%). Within the European Union, Spain has the largest barley area harvested (2.7 million hectares). If barley production is calculated by volume, and not by area, then Russia and Ukraine still remain the leaders, with France and Germany in the third and fourth places, respectively. The yield of barley varies from $0.34 \mathrm{t} / \mathrm{ha}$ to the maximum of $8.21 \mathrm{t} / \mathrm{ha}$ recorded in the United Arab Emirates. With $7.82 \mathrm{t} / \mathrm{ha}$, Ireland ranks second in terms of productivity. The countries of the European Union have the highest productivity in the world. In Russia, the average yield of winter barley is $3.59 \mathrm{t} / \mathrm{ha}$, and of spring barley, $2.18 \mathrm{t} / \mathrm{ha}[3,13,14,19]$.

In Russia, barley is an important food, fodder and industrial crop, occupying $25 \%$ of the total area of grain crops, or 9 million hectares, which indicates the importance of this crop in the grain balance of the country [5, 6]. In Russia, mainly spring barley is cultivated. Over 100 varieties of spring barley and over 40 varieties of winter barley have been zoned in Russia. Many breeding centers across the country are involved in barley breeding [13, 14, 22].

Russia's main producers are the Volga and Central Federal Districts. The largest producing region is the Voronezh region. The Orenburg is in the first place in terms of the barley area harvested. The Southern Federal District accounts for up to $15 \%$ of the total Russian barley production. In the Rostov region, there was an increase in the winter barley area harvested and a decrease in that of the spring barley.

In the Northwest Russia, cereals are mainly grown as livestock feed. The most important crop is spring barley. As of 2019, in the Leningrad Region the barley area harvested amounted to 24.6 thousand hectares, and the gross harvest was 83.6 thousand tons [13, 14]. The creation and introduction of new high-yielding varieties that meet the requirements of modern agricultural production is the most important task for breeders. Crop variety is the most effective and most affordable means of increasing profitability and competitiveness of crop production [18, 19].

In Northwest Russia, development and introduction of new varieties of cereals characterized by early maturity, high adaptive potential and ecological plasticity is one of the most important tasks. Varieties with genetically determined mechanisms of protection against unfavorable environmental factors will produce high and stable yields.
The climate of Northwest Russia has special requirements for newly created crop varieties. In early spring, night frosts are common, which slows down the first stages of organogenesis. Arid conditions in May and excessive moisture in July-August result in that the formed plastic substances do not always become the basis for a high yield [13, 14].

In Northwest Russia, the own production of fodder grain does not exceed $15 \%$ of the demand therefore, the development of animal husbandry depends to a large extent on market conditions and transport tariffs. The main way to increase the production of fodder grain and its value is the development and introduction of new, high-yielding varieties of barley which are maximally adapted to soil and climatic conditions, and modern agricultural technologies. A new generation of barley varieties is needed that combines high yields with early maturity, high feed qualities of grain, resistance to lodging and grain shedding [13, 14].

The creation of varieties resistant to the most harmful diseases (Ustilago hordei, leaf spots) remains topical. Unfortunately, in the last decade, the late-ripening European brewing varieties (Despina, J. Flavour, etc.) with a low grain protein content (no more than $12 \%$ ) have been gaining popularity in the region.

A new Fermerskiy variety of barley has a high grain protein content, $15.1 \%$. One of the reasons for lowering yields is barley lodging. Lodging of crops disrupts the process of assimilation and grain filling, i.e. the yield decreases and grain quality deteriorates. The lodging problem can be solved by breeding varieties with a short stem. Breeding for resistance to lodging and diseases, and improving the quality of grain has been carried out at the Leningrad Institute of Agriculture "Belogorka" for many decades $[13,14]$.

The main method for creating new varieties of spring barley is the method of intervarietal hybridization of ecologically distant forms. Important points are the determination of the main signs of the productivity development of spring barley plants, study of inheritance and the degree of variability, and of most important economic and biological traits, and determination of the possibilities of more effective selection for individual traits that determine the sample productivity. Among traits that determine productivity of spring barley in Northwest Russia, the leading role belongs to productive tillering. This dependence increases in years with insufficient moisture and decreases in wet years. The mass of grain from the ear and its size are among the traits that significantly affect yielding qualities $[17,18]$.

The duration of the growing season is also one of the most important properties that affect the crop amount and quality. The urgency of this problem has increased in recent years. An increase in the yield of new varieties was ensured by an increase in the period of growth and development of plants, which led to a widespread distribution of late-ripening varieties of the Western European type. Their maturation, as a rule, coincides with an increase in moisture supply in July-August. This leads to secondary tillering, slow ripening, difficulty in harvesting, and yield shortage. 
Recently, the phytosanitary state of the crops of spring barley has worsened, and new diseases have appeared, which predetermines the need for selection $[13,15,20]$.

\section{Material and methods}

The research methodology is based on an integrated approach and generally accepted methods. Field and laboratory studies were carried out in an experimental field of the Leningrad Research Institute of Agriculture "Belogorka". During the years of study, the predecessor was potato. Mineral fertilizers in the form of "azofoska" were applied before cultivation at a dose of N60P60K60. The soil of the experimental plots is soddy-podzolic, medium-cultivated, light loamy with a humus content of 2.41-2.80\% (according to Tyurin, as modified by TsINAO), $\mathrm{P}_{2} \mathrm{O}_{5}$ of $140-185$ and $\mathrm{K}_{2} \mathrm{O}$ of $135-150 \mathrm{mg} / \mathrm{kg}$ (according to Kirsanov), and $\mathrm{pH}_{\mathrm{KCL}}$ of 4.0-4.5.

The work comprised experimental (field and laboratory) and statistical (mathematical data processing).

For statistical processing of the data obtained, the analysis of the dispersion factors of the main components (7) and the Spearman's rank correlation method (RS) were used to determine the degree of influence of air temperature on the yield of spring barley [23].

A new variety of spring barley Fermerskiy was bred by the method of intraspecific hybridization and individual selection from the hybrid population N-1998. The genealogy of the variety includes samples of spring barley with a two-row (var. nutans) ear type belonging to the Western European eco-group and spring breeding material of hybrid origin bred by the Leningrad Research Institute of Agriculture "Belogorka" [13, 14].

The study of the material was deployed according to the full scheme of the breeding process, which included obtaining hybrids of the first generation $\left(\mathrm{F}_{1}\right)$, reproduction of a hybrid population in a hybrid nursery $\left(\mathrm{F}_{2}-\mathrm{F}_{5}\right)$, individual selection of elite ears $\left(\mathrm{F}_{6}\right)$, and testing lines in nurseries SP-1, SP-2, KP, PSI and KSI. Field phenological observations, registration of diseases, and crop assessment were carried out. A complete structural analysis of plants has been carried out.

Competitive variety testing of the new Fermerskiy barley variety took place in 2018-2020. The growing seasons during the years of study differed significantly in terms of heat and moisture supply. In May 2018, the period of seed germination and emergence was characterized by an unusually high air temperature of $13.5{ }^{\circ} \mathrm{C}\left(4.2{ }^{\circ} \mathrm{C}\right.$ above the average), and low rainfall of $14.4 \mathrm{~mm}$ (against the average of $52.0 \mathrm{~mm}$ ). In 2019, air temperature was close to an optimal $\left(10.8{ }^{\circ} \mathrm{C}\right)$, and the amount of precipitation was $46 \mathrm{~mm}$ above the average. In 2020 , air temperature was below the average $\left(8.5^{\circ} \mathrm{C}\right)$ and rainfall was also low $(44.3 \mathrm{~mm})$.

In June, the air temperature was the highest (14.6-17.4 ${ }^{\circ} \mathrm{C}$ ) and rainfall, the lowest (15.9-34.4 mm against the average of $65 \mathrm{~mm}$ ) of all years of research. In July 2018, air temperature exceeded the average by $2.0^{\circ} \mathrm{C}$; in July 2019 , it was $2.0{ }^{\circ} \mathrm{C}$ below the average; and in July 2020 , it was close to the optimum $\left(16.0^{\circ} \mathrm{C}\right)$. In the first years of the study, the amount of precipitation was above the average (150.1 and $84.9 \mathrm{~mm})$; and in 2020 , it was slightly below the average $(75.7 \mathrm{~mm})$. In August 2018 and 2020, during the grain ripening period precipitation was above the average of $86.0 \mathrm{~mm}$, i.e. 95.2 and $104.4 \mathrm{~mm}$, respectively. In 2019, the moisture deficit was $46.0 \mathrm{~mm}$, and air temperature close to an optimal $\left(14.7^{\circ} \mathrm{C}\right)$. In 2018 and 2020, air temperature was $0.7-2.0^{\circ} \mathrm{C}$ higher than the average (Table 1 ).

Table 1. Hydrothermal conditions of the growing seasons 2018-2020 (according to data of the Belogorka meteorological station)

\begin{tabular}{|c|c|c|c|c|c|}
\hline \multicolumn{2}{|c|}{ Month } & May & June & July & August \\
\hline \multirow{2}{*}{$\begin{array}{c}\text { Average daily } \\
\text { temperature, } \\
{ }^{\circ} \mathrm{C}\end{array}$} & 2018 & 13.5 & 14.6 & 18.7 & 16.8 \\
\cline { 2 - 6 } & 2019 & 10.8 & 17.3 & 14.7 & 14.7 \\
\cline { 2 - 6 } & 2020 & 8.5 & 17.4 & 16.0 & 15.5 \\
\cline { 2 - 6 } & Mean & 9.3 & 14.0 & 16.7 & 14.8 \\
\hline \multirow{3}{*}{$\begin{array}{c}\text { Precipitation, } \\
\text { mm }\end{array}$} & 2018 & 14.4 & 27.6 & 150.1 & 95.2 \\
\cline { 2 - 6 } & 2019 & 96.0 & 15.9 & 84.9 & 40.0 \\
\cline { 2 - 6 } & 2020 & 44.3 & 34.4 & 75.7 & 104.4 \\
\cline { 2 - 6 } & Mean & 52.0 & 65.0 & 78.0 & 86.0 \\
\hline
\end{tabular}

\section{Results and discussion}

Productivity is one of the main features that characterizes the economic value of a variety. Over three years of study, the average yield of the new Fermerskiy variety was $4.37 \mathrm{t} / \mathrm{ha}$, which is $1.25 \mathrm{t} / \mathrm{ha}$ more than that of Suzdalets (Table 2). At $\mathrm{LSD}_{0.5}-0.344 \mathrm{t} / \mathrm{ha}$, the new variety significantly exceeds the standard $\left(\mathrm{F}_{\text {fact. }}=5.36>\mathrm{F}_{\text {tab. }} 2.21\right.$ at $\left.\mathrm{P}_{0.1}=0.15\right)$.

The analysis of variance showed that heat supply is a determining factor in the yield of both varieties. The temperature regime explains $64 \%$ of the total variation in the dataset. A correlation between yield and air temperature was negative in the case of the Suzdalets standard $(\mathrm{r}=-0.38)$, while the relationship was not significant in the case of the Fermerskiy variety $(\mathrm{r}=-0.22)$.

Table 2. Adaptive traits of the Fermerskiy variety and the Suzdalets standard over the period 2018-2020

\begin{tabular}{|c|c|c|}
\hline Indicators & $\begin{array}{c}\text { Suzdalets } \\
\text { standard }\end{array}$ & $\begin{array}{c}\text { Fermerskiy } \\
\text { variety }\end{array}$ \\
\hline Yield, t/ha & $\begin{array}{c}3.1(\min 2.6- \\
\max 3.7)\end{array}$ & $\begin{array}{c}4.37(\min 3.36- \\
\max 52.7)\end{array}$ \\
\hline $\begin{array}{c}\text { Vegetative period, } \\
\text { days }\end{array}$ & $\begin{array}{c}93.0(\min 81.0- \\
\max 100.0)\end{array}$ & $\begin{array}{c}79.0(\min 72.0- \\
\max 87.0)\end{array}$ \\
\hline Stem height, cm & $\begin{array}{c}60.4(\min 55.7- \\
\max 64.0)\end{array}$ & $\begin{array}{c}64.0(\min 58.1- \\
\max 69.5)\end{array}$ \\
\hline $\begin{array}{c}\mathrm{J}_{\mathrm{sp}}, \text { environmental } \\
\text { plasticity index }\end{array}$ & 1.08 & 1.48 \\
\hline $\begin{array}{c}\text { Adaptive } \\
\text { potential, } \mathrm{d}_{\mathrm{s}} / \mathrm{d}_{\mathrm{k}}\end{array}$ & 7.91 & 7.31 \\
\hline
\end{tabular}

The duration of the growing season of the varieties studied varied from year to year depending on weather conditions. Over three years, on average it was 79.0 days in the case of the new Fermersky variety, which is 14 days less than for the late-ripening Suzdalets variety 
(93.0 days), which is very important for regions with a short growing season.

In breeding practice, the following indices are used: the adaptive potential of plants and the index of ecological plasticity $[13,14,24]$.

The adaptive potential of plants characterizes the resistance of varieties to lodging and determines the plant productivity.

This index is calculated using the formula:

$$
d s / d k
$$

where $d s$ is the length of the stem; $d k$ is the length of the ear.

For breeding purposes, varieties with a stem share in the total plant length of less than 10 units are of value [3]. In the case of the Fermerskiy variety, this indicator is at the level of the highly productive Suzdalets variety, 7.91. The index of ecological plasticity $\left(\mathrm{J}_{\mathrm{sp}}\right)$ shows an advantage of the variety studied over other varieties; it is calculated according to the formula of Eberhart end Rassel [24].

$$
J_{s p}=\frac{S_{s}}{S_{k}}
$$

where $S_{\mathrm{s}}$ is the yield of the variety; $s_{k}$ is the average yield of the varieties in the sample.

Varieties with $\mathrm{J}_{\mathrm{sp}}$ greater than 1 are of interest for breeding. The new Fermerskiy variety's $\mathbf{J}_{\mathrm{sp}}$ is 1.48 units, which is 0.4 units more than that of the Suzdalets variety (1.08 units).

Productive tillering - the number of productive stems per plant - is one of the important traits that determine the yield. Productive tillering of the Fermerskiy variety is 0.2 units higher than that of the Suzdalets variety (Table 3).

Table 3. Economically valuable traits of the Fermerskiy and Suzdalets varieties over the period 2018-2020.

\begin{tabular}{|c|c|c|}
\hline Indicators & $\begin{array}{c}\text { Standard } \\
\text { Suzdalets }\end{array}$ & Fermerskiy variety \\
\hline $\begin{array}{c}\text { Productive tillering, } \\
\text { pcs. }\end{array}$ & $\begin{array}{c}2.61(\min 2.4- \\
\max 2.8)\end{array}$ & $\begin{array}{c}2.8(\min 2.6- \\
\max 3.0)\end{array}$ \\
\hline $\begin{array}{c}\text { Weight of 1,000 } \\
\text { grains, g }\end{array}$ & $\begin{array}{c}43.7(\min 36.30- \\
\max 48.9)\end{array}$ & $\begin{array}{c}48.6(\min 40.6- \\
\max 54.5)\end{array}$ \\
\hline $\begin{array}{c}\text { Grain weight per } \\
\text { plant, g }\end{array}$ & $\begin{array}{c}2.9(\min 2.6- \\
\max 3.4)\end{array}$ & $\begin{array}{c}3.5(\min 3.2- \\
\max 3.8)\end{array}$ \\
\hline $\begin{array}{c}\text { Grain weight from } \\
\text { the main ear, g }\end{array}$ & $\begin{array}{c}1.4(\min 1.1- \\
\max 1.6)\end{array}$ & $\begin{array}{c}1.5(\min 1.2- \\
\max 1.7)\end{array}$ \\
\hline $\begin{array}{c}\text { Quantity of grains in } \\
\text { the ear, pcs. }\end{array}$ & $\begin{array}{c}21.3(\min 20.0- \\
\max 22.0)\end{array}$ & $\begin{array}{c}21.7(\min 20.0- \\
\max 24.0)\end{array}$ \\
\hline Ear length, cm & $8.3(\min 7.8-$ & $8.4(\min 7.1-$ \\
$\max 8.9)$ & $\max 9.0)$ \\
\hline
\end{tabular}

The grain size, expressed in terms of the mass of 1,000 grains, is also one of the most important elements of the crop structure. According to this indicator, the Fermerskiy variety exceeded the Suzdalets standard by $4 \mathrm{~g}$.

Indicators such as the weight of grain from the main ear and the productivity of one plant are closely related to the yield. According to these parameters, the Fermerskiy variety exceeded the Suzdalets standard by 0.12 and $0.62 \mathrm{~g}$, respectively.

The graininess of the ear - the number of grains in the ear - is highly correlated with the productivity of the ear $[13,17,18,20]$ The graininess of the Fermerskiy variety is similar to that of the Suzdalets standard $(21.7 \mathrm{~g})$. The ear length also affects productivity; according to this trait, the new Fermerskiy variety is similar to the Suzdalets standard $(8.4 \mathrm{~cm})$.

The Leningrad Research Institute of Agriculture "Belogorka" traditionally carries out selection for resistance to the most harmful diseases of Northwest Russia. Over three years of study, the damage by dark brown spot of the Suzdalets standard was $20 \%$ on average, and of the new Fermerskiy variety, $10 \%$. According to the Spearman's rank correlation coefficient $\left(R_{s}\right)$, the Fermersky variety is significantly more resistant to leaf spots at the level of $0.05: R_{\mathrm{s}}=0.850$, critical value $R_{s}=0.780$.

The damage by powdery mildew was $35 \%$ of the standard Suzdalets, and $15 \%$, of the Fermerskiy variety. In 2020, an epiphytotic spread of powdery mildew was observed in spring barley crops; $50 \%$ of the Suzdalets standard plants were damaged, against $15 \%$ of the new variety. In the same year, the development of leaf rust on barley plants was noted. The standard Suzdalets was damaged by $15-20 \%$, and the Fermerskiy variety, by $5 \%$.

\section{Conclusion}

A new variety of spring barley Fermerskiy has a high potential yield. In favorable years, the yield can reach $6.0 \mathrm{t} / \mathrm{ha}$. It differs in cold resistance at the first stages of development (seedlings - tillering). Its growing season is 72-87 days, which is two weeks shorter than that of the Suzdalets standard. It has a strong, lodging-resistant straw, and a plant height of $58-64 \mathrm{~cm}$. It is resistant to Ustilago hordei and root rot. It is practically resistant (in some years moderately resistant) to leaf spots (net and dark brown) and powdery mildew.

The Fermerskiy variety is characterized by its large, leveled grain with a weight of 1,000 grains up to $54.5 \mathrm{~g}$. The variety is resistant to shattering and germination of grain. The variety is distinguished by its high adaptability and ecological plasticity. It has good fodder qualities: the protein content is $15.1 \%$, it has a potential as a fodder base for the development of dairy, beef and poultry farming of the Russian Federation. The profitability level of the new Fermerskiy variety is $81.8 \%$.

\section{References}

1. B. AbrhaDelbecque, N. Raes, D. Tsegay, A. Todorovic, M. Heng, L. Vanutrecht, E. Geerts, S. Garcia-Vila, S. Deckers, Sowing strategies for barley (Hordeum vulgare L.) based on modelled yield response to water with AquaCrop, Experim. Agricult., 48, 252-271 (2012)

2. E. Pohanková, P. Hlavinka, M. Orság, J. Takáč, K. Kersebaum, A. Gobin, M. Trnka, Estimating the water use efficiency of spring barley using crop models, J. of Agricult. Sci., 156(5), 628-644 (2018) 
3. O. Gorash, R. Klymyshena, V. Khomina, L Vilchynska, Ecological and biological conformity of conditions of the brewing barley cultivation zone, Ukrain. J. of Ecol., 10(1), 246-253 (2020)

4. G. Fischbeck, In R. von Bothmer, T. van Hintum, H. Knüpffer, K. Sato (Ed.), Diversity in barley (Hordeum vulgare) (Elsevier Science; Diversification through breeding, Amsterdam, 2003), pp. 29-52

5. H.M. Gauger, GmbH Barley Malt World News, Market report 7, August 3 (2015).

6. H. Jones, P. Civáň, J. Cockram, F.J. Leigh, L. Smith et al., Evolutionary history of barley cultivation in Europe revealed by genetic analysis of extant landraces, BMC evolut. Boil., 11, 320 (2011)

7. P. Marcinkowski, M. Piniewski, Effect of climate change on sowing and harvest dates of spring barley and maize in Poland, Int. Agrophys., 32(2) (2018)

8. M. Trnka, P. Hlavinka, D. Semerádová, M. Dubrovský, Z. Žalud, M. Možný, Agricultural drought and spring barley yields in the Czech Republic, Plant, Soil and Envir., 53(7), 306-316 (2007)

9. B. Mužíková, T. Středa, P. Krmelová, O. Dvořáčková, Yields of spring barley in the climatic conditions of the Czech Republic, Kvasny Prum., 59(12), 352-357 (2013)

10. S.G. Thabet, Y.S. Moursi, M.A. Karam, A. Graner, A.M. Alqudah, Genetic basis of drought tolerance during seed germination in barley, PLoS One, 13(11), e0206682 (2018)

11. K. Mikołajczak, P. Ogrodowicz, K. Gudyś, K. Krystkowiak, A. Sawikowska, W. Frohmberg et al., Quantitative Trait Loci for Yield and YieldRelated Traits in Spring Barley Populations Derived from Crosses between European and Syrian Cultivars, PLoS One 11(5), e0155938 (2016)

12. R. Sharma, S. Shaaf, K. Neumann, Y. Go et al., Bon the origin of photoperiod non-responsiveness in barley, bioRxiv (2020)

13. L.M. Bondareva, T.N. Radyukevich, L.I. Kartasheva, D.A. Danilov, Complex resistance to leaf diseases of spring barley in Leningrad region, Advan. in Engin. Res., 151, 1-7 (2018)

14. L. Bondareva, D. Danilov, L. Kartashova, Breeding spring barley for ecological plasticity and adaptability in the North-Western Region, BIO Web Conf., 27 (2020)
15. M. Wiegmann, A. Maurer, A. Pham, T.J. March, A. Al-Abdallat, et al., Barley yield formation under abiotic stress depends on the interplay between flowering time genes and environmental cues, Sci. Rep., 9, 6397 (2019)

16. J. Russell, M. Mascher, I.K. Dawson, S Kyriakidis, C. Calixto et al., Exome sequencing of geographically diverse barley landraces and wild relatives gives insights into environmental adaptation, Nat. Genet., 48, 1024-1030 (2016)

17. S. Hübner, M. Höffken, E. Oren, G. Haseneyer, N. Stein et al., Strong correlation of wild barley (Hordeum spontaneum) population structure with temperature and precipitation variation, Mol. Ecol., 18, 1523-1536 (2009)

18. P. Herzig, A. Maurer, V. Draba, R. Sharma, F. Draicchio et al., Contrasting genetic regulation of plant development in wild barley grown in two european environments revealed by nested association mapping, J. Exp. Bot., 69, 1517-1531 (2018)

19. I.Y. Zaytseva, L.V. Mamaeva, I.N. Shchennikova, L.P. Kokina, E.V. Dyagileva, Initial material for breeding drought-resistant varieties of spring barley in the conditions of the Volga-Vyatka region, E3S Web Conf., 254 (2021)

20. M. Wiegmann, A. Maurer, A. Pham et al., Barley yield formation under abiotic stress depends on the interplay between flowering time genes and environmental cues, Sci. Rep., 9, 6397 (2019)

21. M. Gómez-Garrido, S. Martínez-Martínez, Á. Faz Cano, A. Büyükkilif-Yanardag, J. Arocena, Soil fertility status and nutrients provided to spring barley (Hordeum distichon L.) by pig slurry, Chil. J. Agric. Res., scielocl. (2014)

22. W. Friedt, F. Ordon, Barley Production and Breeding in Europe: Modern Cultivars Combine Disease Resistance, Malting Quality and High Yield, In G. Zhang, C. Li, X. Liu (Ed.), Advance in Barley Sciences (Springer, Dordrech, 2013)

23. D.K. Vohnout, Mathematical modeling for system analysis in agricultural research (Elsevier Science B.V. Sara Burgerharhartstraat 25P.O. Box 211,1000 AE Amsterdam, The Netherland, 2003), 452 p.

24. S.A. Eberhart, W.A. Rassel, Stability parameters for comparing varieties, Crop. Sci., 6(1), 36-40 (1966) 